\title{
Barriers to Climate Change Adaptation Among Farming Households of Southern Nigeria
}

\author{
Nicholas Ozor ${ }^{1}$, Madukwe M.C. ${ }^{1}$, Enete A.A. ${ }^{2}$, Amaechina E.C. ${ }^{2}$, Onokala P. ${ }^{3}$, \\ Eboh E.C. ${ }^{4}$, Ujah O. ${ }^{4}$, and Garforth C.J. ${ }^{5}$ \\ 1 Department of Agricultural Extension, University of Nigeria, Nsukka \\ 2 Department of Agricultural Economics, University of Nigeria, Nsukka \\ 3 Department of Geography, University of Nigeria, Nsukka \\ 4 African Institute for Applied Economics, Enugu \\ 5 International and Rural Development Department, University of Reading, UK \\ ${ }^{1}$ Corresponding author: sunny ozor@yahoo.com; nicholas.ozor@unn.edu.ng \\ Mobile: +2348035781264
}

\begin{abstract}
Climate change is perhaps the most serious environmental threat to the fight against hunger, malnutrition, disease and poverty in Africa, essentially because of its impact on agricultural productivity. The objective of this paper was to identify the major barriers to climate change adaptation among smallholder farmers of Southern Nigeria. The paper was based on primary data collected within the framework of the Development Partnership for Higher Education (DeIPHE) Project from 360 farming households selected randomly from the region. The data was analyzed using descriptive statistics and factor analysis. The result of the analysis show that majority of the farmers were men (70\%), relatively educated (average of 9 years in school) and practiced mixed farming (61\%). The major factors constraining farmers from adapting to climate change impacts were - (a) land constraints which manifested itself in limited availability, high costs and poor ownership systems (tenure); (b) poor climate change information and agricultural extension service delivery; (c) high cost of farm inputs and processing facilities; (d) high cost of irrigation facilities and government irresponsiveness to climate change risk management, (e) credit constraints, (f) labour constraints, and (g) income constraints. The paper concludes with a recommendation that farmers need to be supported in order for them to effectively adapt to the climate change impacts that are already affecting their production and hence reduce hunger and poverty. These supports could come from governments, non-governmental organizations and even farmers' unions themselves.
\end{abstract}

Keywords: Barriers, Climate change, Adaptation, Farmers, Southern Nigeria

\section{Introduction}

Climate change is perhaps the most serious environmental threat facing mankind worldwide. It has been defined by the Intergovernmental Panel on Climate Change, IPCC (2001) as statistically significant variations in climate that persist for an extended period, typically decades or longer. It includes shifts in the frequency and magnitude of sporadic weather events as well as the slow continuous rise in global mean surface temperature. Climate, water resources, biophysical and socioeconomic systems are interconnected in complex ways, so a change in any one of these induces a change in another. It affects agriculture for instance in several ways, one of which is its direct impact on food production. Besides, almost all sectors in agriculture (crop, livestock, pastoralism, fishery, etc) depend on weather and climate 
whose variability have meant that rural farmers who implement their regular annual farm business plans risks total failure due to climate change effects (Ozor et al, 2010). The vulnerability of the developing countries like Nigeria is worsened by heavy reliance on renewable natural resources for livelihoods, employment and incomes.

Agriculture contributes about $40 \%$ to Nigeria's Gross Domestic Product (GDP), is the main source of food, employs $70-80 \%$ of the population and production in most of the sectors is dependent on weather and climate (Ozor, 2009). Climatic change, which is attributable to natural climate cycle and human activities, has adversely affected agricultural productivity in Africa (Ziervogel et al., 2006). As the planet warms, rainfall patterns shift, and extreme events such as droughts, floods, and forest fires become more frequent (Zoellick, 2009). This results in poor and unpredictable yields, thereby making farmers more vulnerable, particularly in Africa (UNFCCC, 2007). Farmers (who constitute the bulk of the poor in Africa) face challenges of tragic crop failures, reduced agricultural productivity, increased hunger, malnutrition and diseases (Zoellick, 2009). It is projected that crop yield in Africa may fall by $10-20 \%$ by 2050 or even up to $50 \%$ due to climate change (Jones and Thornton, 2003), particularly because African agriculture is predominantly rain-fed and hence fundamentally dependent on the vagaries of weather. As the people of Africa strive to overcome poverty and advance economic growth, this phenomenon threatens to deepen vulnerabilities, erode hard-won gains and seriously undermine prospects for development (WBGU, 2004 and Zoellick, 2009). There is therefore the need for concerted efforts toward tackling this menace.

Much of climatic change agricultural research has tended to concentrate on assessing the sensitivity of various attributes of crop systems (e.g. crop/livestock yields, pest, diseases, weeds etc) - the bio-physical aspects of food production, with little or no regard to the socioeconomic aspects. These partial assessments, most often consider climatic change effects in isolation, providing little insight into what and how they are doing to cope with climate change and especially what constrain them from adapting. To better address the food security concerns that are central to economic and sustainable development agenda especially the millennium development goals (MDGs), it is desirable to also address these aspects of climate change and agriculture. Wisner et al (2004) reports that the vulnerability of agriculture is not determined by the nature and magnitude of environmental stress like climate change per se, but by the combination of the societal capacity to cope with and/or recover from environmental change. While the coping capacity and degree of exposure is related to environmental changes, they are both also related to changes in societal aspects such as land use and cultural practices. This paper discusses the barriers encountered by farmers in adapting to climate change in Southern Nigeria. The paper is based on primary data collected within the framework of Development Partnerships in Higher Education (DelPHE) Project 326, which was funded by the British Department for International Development (DFID).

\section{Purpose and objectives}

The overall purpose of the study was to identify the barriers to climate change adaptation among farming households of Southern Nigeria. Specifically, the paper sought to:

1. Characterize the farming households in Southern Nigeria; and 
2. Identify the barriers to climate change adaptation among farming households of Southern Nigeria.

\section{Methodology \\ The Study area}

The study area is Southern Nigeria (Figure 1). Southern Nigeria is made up of three geopolitical zones namely; Southeast, Southwest, and South-south zones. Its climate is characterized by strong latitudinal zones, becoming progressively drier as one moves north from the coast. Rainfall is the key climatic variable, and there is a marked alternation of wet and dry seasons in most areas. Two air masses control rainfall - moist northward-moving maritime air coming from the Atlantic Ocean and dry continental air coming south from the African landmass.

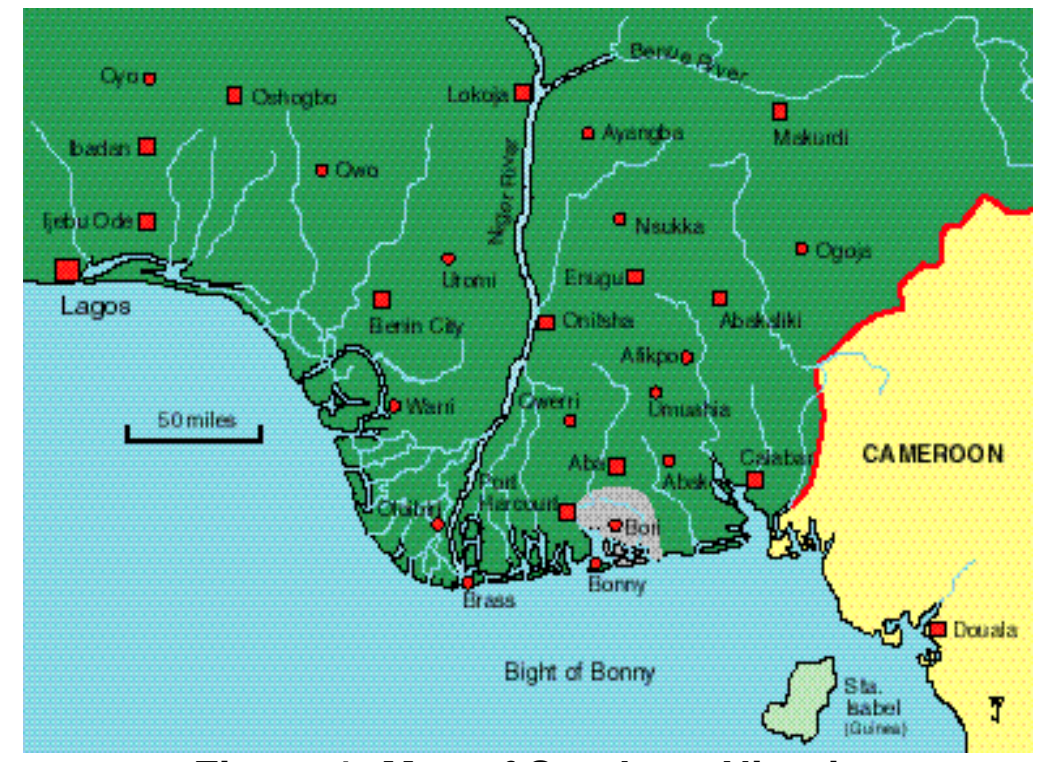

Figure 1: Map of Southern Nigeria

The rainy season usually begins in February or March as moist Atlantic air, known as the southwest monsoon, invades the country. The beginning of the rains is usually marked by the incidence of high winds and heavy but scattered squalls. By April or early May in most years, the rainy season is under way throughout most of the area. The usual peak of the rainy season occurs through most of southern Nigeria in July with a dip in precipitation during the month of August. Although rarely completely dry, this August dip in rainfall, which is especially marked in the southwest, can be useful agriculturally, because it allows a brief dry period for grain harvesting.

From September through November, the northeast trade winds generally bring a season of clear skies, moderate temperatures, and lower humidity for most of the country. From December through February, however, the northeast trade winds blow strongly and often bring with them a load of fine dust from the Sahara. These dust-laden winds, known locally as the harmattan, often appear as a dense fog and cover everything with a layer of fine particles.

The greatest total precipitation is generally in the South-south, along the coast around Bonny (south of Port Harcourt) and east of Calabar, where the mean annual rainfall is more than 4,000 millimeters. Most of the rest of the South-south and Southeast receives between 2,000 and 3,000 millimeters of rain per year, and the 
Southwest (lying farther north) receives lower total rainfall, generally between 1,250 and 2,500 millimeters per year. Mean annual precipitation at Lagos is about 1,900 millimeters; at Ibadan, only about 140 kilometers north of Lagos, mean annual rainfall drops to around 1,250 millimeters. Moving north from Ibadan, mean annual rainfall in the West is in the range of 1,200 to 1,300 millimeters.

Temperatures throughout Nigeria are generally high; diurnal variations are more pronounced than seasonal ones. Highest temperatures occur during the dry season; rains moderate afternoon highs during the wet season.

The economy of Nigeria historically was based on agriculture, and about $70 \%$ of the workforce is still engaged in farming (largely of a subsistence type). The chief crops are cocoa, peanuts, palm oil, corn, rice, sorghum, millet, soybeans, cassava, yams, and rubber. In addition, cattle, sheep, goats, and pigs are raised as livestock.

The distribution of vegetation in Southern Nigeria is dependent mainly on the climate, which becomes increasingly drier further inland from the coast. Climatic zones, therefore, run roughly parallel to the coast, widening or narrowing as geographical features alter the steepness of the climatic gradient. This climatic zoning has resulted in a vegetation zoning, comprising the rain forest zone, the mixed deciduous forest zone, and the parkland zone. The first two are climax systems, but the parkland zone is probably caused by anthropogenic conversion of forest and is maintained by annual bush fires. The natural vegetation of the parkland zone would probably be mixed deciduous forest. Typical mean annual rainfall varies from 2,000 to 2,500 millimeters $(\mathrm{mm})$ in the rain forest zone near the coast to 1,500 to $2,000 \mathrm{~mm}$ in the mixed deciduous forest zone.

\section{Sampling procedure and data collection}

Multistage random sampling was employed in the selection of respondents for the study, which covered the three geopolitical zones of Southern Nigeria. In each zone, two states were randomly selected to make a total of six states. These were Abia and Enugu in Southeast, Cross River and Delta in South-south, Ogun and Ondo in southwest. In each state, two agricultural zones were randomly selected to make a total of twelve agricultural zones for the study. These were Umuahia and Aba in Abia state, Enugu and Nsukka in Enugu state, Ikom and Calabar in Cross River state, Delta Central and Delta North in Delta state, Rainforest and Savanna in Ogun state, Ondo central and Ondo North in Ondo state. With the assistance of the respective State extension services departments, one farming community was randomly selected from each agricultural zone, to make a total of twelve communities for the study. These were Oboro and azumini in Abia State, Umulungbe and Edem in Enugu State, Ugep and Nkpatum in Cross River State, Okpe and Okoamako in Delta State, Imala and ijebu-ode in Ogun State and Emureile and Adofure in Ondo State. In each community, also with the assistance of the local extension personnel, a list of farm households was compiled and then thirty farmers randomly selected, making a total of three hundred and sixty (360) farmers for the study. The data collected included socioeconomic characteristics of the respondents and problems encountered in coping with climate change among many others.

\section{Data analysis}

Data from the study were analyzed using both descriptive and inferential statistics. Objective one was analyzed using descriptive statistics including percentage and mean scores, while objective two was analyzed using factor analysis 
with varimax rotation. Only variables with factor loadings of 0.40 and above at $10 \%$ overlapping variance were used in naming the factors. Variables that have factor loading of less than 0.40 were not used while variables that loaded in more than one constraints were also discarded (Madukwe, 2004).

\section{Results and discussions \\ Socioeconomic Characteristics of Respondents}

Results from the study show that majority (70\%) of the respondents were male heads of households, while about $30 \%$ of them were women heads of households. Nweke and Enete (1999) made similar observation across six countries of subSaharan Africa. Bukh (1979) reported that men are most often the heads of households in Africa. They were aged about 49 years on the average with the oldest being 103 years and the youngest being 19 years. This suggests that the farmers were within the economically active age of below 60 years. This is contrary to the expectation that as a result of rural-urban migration, farming has been left to the very old. However, with the current high rate of unemployment, young people may have been resorting to farming. Their average years of farming experience was 22 years with the most and least experienced farmer having 60 and 10 years respectively. Majority $(81 \%)$ of the respondents were married while the remaining $19 \%$ were distributed between widowed (9\%), Single (7\%), divorced (2\%) and separated (1\%).

A small number (16\%) of the respondents had no certificate to show for their level of education, while majority (35\%) had First School Leaving Certificate. About $30 \%$ of them had secondary school certificate, $10 \%$ had Ordinary National Diploma, and $8 \%$ had First Degree while $1 \%$ had Masters Degree. On the average, the respondents had about 9 years of formal education. This is in line with the above observation that unemployment may have driven educated young people back to the farm.

The average household size was about 7 persons with a minimum of one person and a maximum of 20 persons per household. Enete and Okon (2010) observed that $60 \%$ of the farmers in their sample had household size ranging from 58 persons. Farming was the major occupation for $71 \%$ of the respondents while $4 \%$ reported that they were artisans as major occupation. Those who were traders were about $10 \%$ of the respondents, $12 \%$ were public servants, while the remaining $3 \%$ had other occupations. This is not surprising as the study was targeted at full time farmers.

Mixed farming was the predominant activity for about $61 \%$ of the respondents. The remaining percentage was shared between crop farming $(35 \%)$ and livestock farming (4\%). Mixed farming is generally the most popular farming activity in the country, particularly in the Southern part of the country. Mixed farming is always preferred in order to guard against crop or animal failure. Again, the manure from animals is usually used as cheap organic fertilizers for the crops while the crop residues after harvest serve as fodder materials for the animals.

\section{Crops and animals grown/reared in the area}

The first most important crop in the area was Cassava, as ranked by $59 \%$ of the respondents (Table 1). Cassava is not only a major staple but also a major source of farm income for the Nigerian farmers (Nweke, 1996). And compared to other crops, cassava is the most resistant to extreme weather events. It is therefore most often described as a hardy crop and may in this sense be the most adaptable 
crop to climate variations (Enete, 2003). Benhin (2006) reported that one of the strategies which served as an important form of insurance against rainfall variability is increasing diversification by planting crops that are drought tolerant and/or resistant to temperature stresses.

Cassava was followed by yam and maize with about $12 \%$ and $6 \%$ respectively of the respondents ranking them as the first most important crop. Yam is the second most important root crop after cassava, especially in Southeast Nigeria, where there is generally an annual celebration in honour of the crop in most part of the zone. This was followed by cocoyam as ranked by $5 \%$, cocoa and melon by $4 \%$ each, rice and vegetables as ranked by $3 \%$ each, cashew by $2 \%$, cowpea/beans and plantain/banana by $1 \%$ each of the respondents. Regarding the trend of crop yield in the last ten years, majority (48\%) of the respondents reported that it has been decreasing, 34\% reported increasing, while 18\% suggested that there has been no change in the trend of crop yield in the last ten years.

Table 1: Percentage distribution of respondents by most important crops/animals grown/reared $(n=358)$

\begin{tabular}{llll}
\hline $\begin{array}{l}\text { Most important } \\
\text { crop }\end{array}$ & Percentage & Most important animal & Percentage \\
\hline Cassava & 59 & Poultry & 58 \\
Yam & 12 & Goat & 32 \\
Cocoyam & 5 & Sheep & 3 \\
Maize & 6 & Cattle & 0.5 \\
Rice & 3 & Rabbit & 0.5 \\
Cowpea/Beans & 1 & Pig & 3 \\
Vegetables & 3 & Fish & 3 \\
Cocoa & 4 & & \\
Melon & 4 & & \\
Plantain/Banana & 1 & & \\
Cashew & 2 & & \\
\hline
\end{tabular}

On the other hand, the most popular (58\%) animal reared in the area was poultry as it was ranked first by the respondents (Table 1). About $32 \%$ ranked goat as most important while only $3 \%$ of the respondents ranked sheep, pig and fish respectively. Cattle and rabbit were ranked by about $0.5 \%$ each by the respondents as the first most important animal reared in the area.

On the trend of number of animals produced, majority $(37 \%)$ of the respondents suggested that production has been on the increase; about $34 \%$ reported no change, while $29 \%$ said the trend has been on the decrease. Since crops are usually the first casualty of weather variations, it is possible that farmers in the area may have been increasing their animal stock as a means of climate change adaptation. 
Table 2 shows the barriers to effective climate change adaptation among farming households in Southern Nigeria. Data in the table show that seven factors were mainly responsible for the difficulties in adaptation to climate change by the respondents. These factors include; land constraints (factor 1), poor climate change information and agricultural extension service delivery (factor 2), high cost of farm inputs and processing facilities (factor 3 ), high cost of irrigation facilities and government irresponsiveness to climate change risk management (factor 4), credit constraints (factor 5), labour constraints (factor 6), and income constraints (factor 7).

\section{Table 2: Barriers to climate change adaptation among farming households} $(n=360)$

\begin{tabular}{|c|c|c|c|c|c|c|c|}
\hline \multirow[b]{2}{*}{ Constraint items } & \multicolumn{7}{|c|}{ Component factors $^{*}$} \\
\hline & 1 & 2 & 3 & 4 & 5 & 6 & 7 \\
\hline Limited availability of land for farming & .863 & .020 & .028 & -.072 & .135 & .146 & -.069 \\
\hline High cost of farmland & .786 & -.065 & .283 & -.008 & -.012 & .141 & -.140 \\
\hline Inherited system of land ownership & .786 & .109 & .052 & .013 & -.008 & .046 & .187 \\
\hline Communal system of land ownership & .697 & .035 & -042 & .221 & .299 & .166 & .023 \\
\hline Poor access to information sources & .221 & .535 & .010 & -.177 & .523 & -.005 & -.098 \\
\hline Non-availability of credit facilities & .101 & .085 & .162 & -.008 & .828 & .096 & .137 \\
\hline High cost of irrigation facilities & .088 & -.167 & .076 & .718 & .234 & .040 & -.249 \\
\hline $\begin{array}{l}\text { Non-availability of farm inputs e.g. } \\
\text { improved seeds }\end{array}$ & .049 & -.079 & .600 & .262 & .390 & .082 & -.036 \\
\hline high cost of fertilizers and other inputs & .476 & .074 & .175 & .032 & .533 & .039 & .221 \\
\hline $\begin{array}{l}\text { Inadequate knowledge of how to cope } \\
\text { or build resilience }\end{array}$ & .488 & .400 & .009 & -.041 & .212 & -.296 & .337 \\
\hline High cost of improved varieties & .175 & .124 & .862 & .082 & .086 & .053 & -.045 \\
\hline Non-availability of farm labour & .279 & .015 & .053 & .313 & .027 & .729 & -.075 \\
\hline High cost of farm labour & .133 & .105 & .192 & -.055 & .134 & .765 & .212 \\
\hline $\begin{array}{l}\text { Lack of access to weather forecast } \\
\text { technologies }\end{array}$ & .253 & .567 & .014 & .333 & .212 & -.294 & -.013 \\
\hline $\begin{array}{l}\text { Government irresponsiveness to } \\
\text { climate risk management }\end{array}$ & .091 & .242 & .010 & .546 & -.190 & -.015 & .214 \\
\hline Non-availability of storage facilities & -.085 & -.014 & .428 & .646 & -.075 & .195 & .057 \\
\hline Limited income & .147 & .052 & .233 & .052 & .287 & .312 & .676 \\
\hline Non-availability of processing facilities & -.124 & -.103 & .555 & .556 & -.034 & .116 & .058 \\
\hline High cost of processing facilities & .252 & .122 & .652 & .064 & .105 & .170 & .375 \\
\hline $\begin{array}{l}\text { Traditional beliefs/ practices e.g. on } \\
\text { the commencement of farming season } \\
\text { etc }\end{array}$ & .284 & .357 & .250 & .067 & .027 & .357 & -.477 \\
\hline $\begin{array}{l}\text { Poor agricultural extension service } \\
\text { delivery }\end{array}$ & -.049 & .844 & .188 & -.078 & .075 & .102 & -.033 \\
\hline $\begin{array}{l}\text { Lack of capacity of extension } \\
\text { personnel to build resilience capacity } \\
\text { of farmers on climate change }\end{array}$ & .000 & .869 & .155 & -.020 & -.055 & .136 & -.040 \\
\hline $\begin{array}{l}\text { Poor information on early warning } \\
\text { systems }\end{array}$ & .022 & .776 & .284 & .045 & .039 & .006 & .161 \\
\hline
\end{tabular}


The specific issues that amplified land constraints (factor 1) include; limited availability of land for farming $(0,863)$, high cost of farmland $(0.786)$, inherited system of land ownership (0.786) and communal system of land ownership (0.697). In traditional societies, individual farmers do not usually have title to farmland but enjoy user rights, which could be withdrawn at any time by the custodian of the communal land. Benhin (2006) noted that farm size and land tenure status are some of the major determinants of speed of adoption of adaptation measures to climate change.

Under factor 2 (poor climate change information and agricultural extension service delivery), the factors that loaded high were; lack of access to weather forecast technologies (0.567), poor information on early warning systems $(0.776)$, poor agricultural extension service delivery (0.844) and lack of capacity of extension personnel to build resilience capacity of farmers on climate change $(0.869)$. In the present information age, information problems could pose serious challenges to farmers' coping strategies as they may not be aware of recent developments regarding climate change adaptations and the necessary readjustments needed. The lack of adaptive capacity due to constraints on resources such as the lack of access to weather forecasts creates serious gaps between the farmers and useful information that should help them in their farm work. Weather forecasts are supposed to guide farmers on climate variability so that they can make informed decisions and useful farm plans. However, the absence of this facility will undoubtedly make the farmers become ignorant of the weather situations and hence become vulnerable to the impact of changes in the climate and weather.

The variables that loaded high under factor 3 (high cost of farm inputs and processing facilities) include high cost of improved varieties (0.862), non-availability of farm inputs (0.600) and high cost of processing facilities (0.652). All these variables suggest scarcity of resource inputs, which raise their prices beyond the reach of the farmers. This could pose threats to the coping strategies of the farmers. As noted by Reilly (1996), climate change might constitute significant addition to the stresses already borne by farmers such that adapting to it might be beyond their resource capabilities.

Regarding factor 4 (high cost of irrigation facilities and government irresponsiveness to climate change risk management), the variables that loaded include high cost of irrigation facilities (0.718) and government irresponsiveness to climate risk management (0.546). According to Deressa (2008), poor irrigation potentials can most probably be associated with the inability of farmers to use the already existing water due to technological incapability. Most African farmers are resource poor and cannot afford to invest on irrigation technology for climate change adaptation so as to sustain their livelihood during harsh climate extremes such as flooding and drought. In addition, government institutions responsible for climate change issues in Nigeria, like every other government institutions in most developing countries are still weak and irresponsive to the yearnings of the people.

Factor 5 (credit constraint) just have one variable loaded - non-availability of credit facilities (0.828). The result of a study conducted by Centre for Environmental Economics and Policy in Africa across African countries showed that lack of access to credit is a major problem encountered by farmers in adapting to the effects of climate change (Benhin, 2006). Enete and Achike (2008) also noted that undercapitalized farmers fail to adopt the required level of agricultural technologies that will ensure profitable return. 
Under factor 6 (labour constraints), the variables that loaded include nonavailability of farm labour (0.729) and high cost of farm labour (0.765). Some analyses of barriers to climate change adaptation show that shortage of farm labour is one of the major constraints to adaptation by farmers (Deressa, 2008).

In factor 7 (income constraint), only one variable; limited income (0.676) loaded. This is essentially related to factor 6 , all of which point to lack of money by the farmers as a constraint to adaptation. Lack of money hinders farmers from getting the necessary resources and technologies which facilitates adaptation to climate change. Adaptation to climate change is costly and this cost could be revealed through the need for intensive labour use. Thus, if farmers do not have sufficient family labour or the financial capacity to hire labour, they cannot adapt to climate change. Moreover, Deressa (2008) reported that most of the problems or constraints encountered by farmers in adaptation to climate change are associated with poverty.

\section{Conclusion and recommendations}

Climate change is perhaps the most serious environmental threat to the fight against hunger, malnutrition, disease and poverty in Africa, essentially because of its impact on agricultural productivity. The study confirms that young adults still take up farming as their major occupation in the rural areas. It showed that the major staple crops of these farmers were cassava, yam and maize; while the most important animals reared were poultry and goats. However, mixed farming was the most popular farming activity in the region. Again, the study identified the major barriers to effective climate change adaptation among farming households in Southern Nigeria. These factors include; land constraints, poor climate change information and agricultural extension service delivery, high cost of farm inputs and processing facilities, high cost of irrigation facilities and government irresponsiveness to climate change risk management, credit constraints, labour constraints, and income constraints.

Every adaptation effort results from both intrinsic and extrinsic factors. Intrinsic factors are the efforts made by the vulnerable people themselves (farming households in this case) such as farmers, farmer associations, rural youth associations, community groups, etc; while extrinsic factors are the efforts from external people including governmental agencies, non-governmental agencies, Donor agencies, civil society organizations, etc. Integrating these efforts in a synergistic manner usually results in a more effective adaptation to climate change impacts. However, judging from the poor rural background of most farming households in Nigeria (and in most developing societies), farmers will surely need extrinsic supports in order to be able to break the barriers to effective climate change adaptation.

\section{Acknowledgements}

We wish to thank the British Department for International Development (DFID) for providing the funds used to conduct this research under the Development Partnerships in Higher Education (DeIPHE) programme. We appreciate the British Council, Nigeria for the effective implementation of the DeIPHE programmes in Nigeria and all the participating institutions in the DelPHE 326 Project including; University of Nigeria, Nsukka (UNN); African Institute for Applied Economics (AIAE), Enugu; and the University of Reading (UoR), United Kingdom. 


\section{References}

Benhin, J.K.A. (2006) Climate change and South African agriculture: Impacts and adaptation options. Centre for Environmental Economics and Policy for Africa (CEEPA) Discussion paper No. 21. CEEPA, University of Pretoria, South Africa.

Bukh, J. (1979) The village woman in Ghana. Centre for Development Research publications series 1. Scandinavian Institute of African Studies, Uppsala, Sweden.

Deressa, T. (2008) Analysis of perception and adaptation to climate change in the Nile Basin of Ethiopia. An unpublished Ph .D. thesis, Centre for Environmental Economics and Policy for Africa (CEEPA), University of Pretoria, South Africa.

Enete, A.A. and Achike, I..A (2008) Urban Agriculture and Food Insecurity/Poverty in Nigeria; the case of Ohafia-Southeast Nigeria. Outlook on Agriculture Vol. 37, No 2, pp 131-134.

Enete, A.A. (2003) "Resource Use, Marketing and Diversification Decisions in Cassava Producing Household of Sub-Saharan Africa". A Ph.D Dissertation Presented to the Department of Agricultural Economics, Catholic University of Louvain, Belgium.

Enete, A.A. and Okon U.E. (2010) Economics of waterleaf production in Akwa lbom State. Field Action Science Reports (FACTS), Vol 4.

German Advisory Council on Global Change (WBGU) (2004) World in Transition: Fighting Poverty through Environmental Policy. Earthscan, London.

Intergovernmental Panel on Climate Change, IPCC (ed) (2001) Climate Change 2001: Impact, Adaptation and Vulnerability. Contribution of Working Group II of the Intergovernmental Panel on Climate Change to the Third Assessment Report of IPCC. London: Cambridge University Press.

Jones, P.G. and Thornton, P.K. (2003) Croppers to livestock keepers: Livelihood transition to 2010 in Africa due to climate change. Global Environmental Change, World Health Organization, Geneva, Switzerland.

Madukwe, M.C. (2004) "Multivariate Analysis for Agricultural Extension Research". In: Terry. A. O. (ed) Research Methods in Agricultural Extension. Pp 206 236.

Nweke, F.I. and A.A. Enete (1999) Gender surprises in food production, processing and marketing with emphasis on cassava in Africa. COSCA working paper No. 19, COSCA, IITA, Ibadan, Nigeria.

Nweke, F.I. (1996) Cassava: A cash crop in Africa. COSCA working paper No. 14, COSCA, IITA, Ibadan, Nigeria.

Ozor, N. (2009) Implications of Climate Change for National Development: The Way Forward. Debating Policy Options for National Development; Enugu Forum Policy Paper 10; African Institute for Applied Economics (AIAE); Enugu, Nigeria: 19-32. Available online at: http://www.aiaenigeria.org/Publications/Policypaper10.pdf (viewed 14 November 2009).

Ozor, N; Madukwe, M.C.; Onokala, P.C; Enete, A.; Garforth, C.J.; Eboh, E.; Ujah, O.; and Amaechina, E.; (2010). A Framework for Agricultural Adaptation to Climate Change in Southern Nigeria. A Development Partnerships in Higher Education (DeIPHE) 326 Project Executive Summary supported by DFID and implemented by the British Council; Enugu; African Institute for Applied Economics. 
Reilly, J. (1996) Climate change, global agriculture and regional vulnerability. In: Global climate change and agricultural production. Direct and indirect effects of changing hydrological, pedological and plant physiological processes, Bazzaz, F. and W. Sombroek (eds.). FAO, Rome and John wiley \& Sons, Chichester. Chapter 10.

United Nations Framework Convention on Climate Change (UNFCCC) (2007) Climatic Change Impact, Vulnerabilities and Adaptation in Developing Countries UNFCCC Secretariat, Martin-Luther-King-Straat 853175 Bonn, Germany. www.unfccc.int

Wisner, B., P. Blaikie, T. Cannon and I. Davis (2004) At risk: natural hazards; people's vulnerability and disasters. $2^{\text {nd }}$ Edition. Routledge, London.

Ziervogel G., A. Nyong, B. Osman, C. Conde, S. Cortes, and T. Dowing (2006) Climate variability and change: implications for household food security. Assessments of Impacts and Adaptations to Climate Change (AIACC) Working Paper No. 20, January 2006. The AIACC Project Office, International START Secretariat, Washington DC, USA.

Zoellick, Robert B. (2009) A Climate Smart Future. The Nation Newspapers. Vintage Press Limited, Lagos, Nigeria. Page 18. 